支部・集談会記事

\section{日本臨床外科学会北海道支部抄録 (第116回北海道支部例会)}

\author{
会 期：2019年 9 月 21 日（土）・22日 \\ 会 場 : 北海道大学学術交流会館 \\ 支部長：竹政 伊知朗 \\ 会 長：武冨 紹信
}

\begin{abstract}
一般演題
1 長期経過の後に䅡部食道切開で摘出したブリッジ型有 銁義歯による食道異物の 1 例

旭川医科大学 外科学講座 消化管外科学分野 1 、旭川医科大学 外科学講座 肝胆膵 $\cdot$ 移植外科学分野 2

松下和香子1、長谷川公治1、岩田浩義1、大谷将秀1、宮本正之 1 、 谷 誓良 1 、庄中達也 ${ }^{1}$ 、古川博之 ${ }^{2}$ 、松野直徒 2 、角 泰雄 ${ }^{1}$

症例は60歳代女性. 統合失調症に対し加療中, 〈も膜下出血の治 療で他院脳神経外科に入院していた際に義歯の紛失があった. 食 道の詰り感の訴えがあったが17日後退院, 翌日自宅で意識障害を 認め救急搬送された。搬送時の CT で頚部食道に異物を認め, 上部 消化管内視鏡検查で頚部食道にブリッジ型有鈎義歯を認めた。一 部は食道前壁に刺入し潰瘍形成していたが, 穿孔している所見は なく, 食道造影検查でも穿孔所見は認めなかった. 内視鏡的に摘 出を試みたが抵抗あり，摘出することも胃内へ押すこともできず 内視鏡的摘出は困難と判断し手術を施行した. 頚部食道左側壁を $4 \mathrm{~cm}$ 切開して義歯を摘出. 食道壁は層々に 2 層で閉鎖し, 胃瘦を 造設した。術後合併症なく第25病日に退院した。食道異物は内視 鏡的摘出が望ましいが, ブリッジ型有鈎義歯は大型で粘膜を損傷, 刺入することがある.内視鏡的摘出が困難な際は手術による摘出 が必要である.また、義歯紛失時には画像評価をすることも重要 である。
\end{abstract}

\section{2 異なる契機で発症した食道損傷 2 例の治療経験 函館五稜郭病院 外科}

小熊貴之、吉田瑛司、小林 慎、高橋智子、川岸涼子、佐藤 慧、 武田大樹、河野 剛、千葉丈広、米澤仁志、船渡 治、高金明典 【はじめに】食道損傷の原因には特発性、医原性、外傷性、異物 性などがある。今回、異なる契機で発症した食道損傷 2 例を経験 したので報告する。【症例 1】80歳男性。前医のX 線検査で頚部 に義歯を認めたが内視鏡的除去困難であり手術目的に当院に紹 介。左側䅡部よりアプローチ、食道を露出すると義歯を触知した。 同部位で食道を切開し義歯を除去、切開部を縫合閉鎖した。術後 第 8 病日に自宅退院となった。【症例 2】75歳男性。便器に腹部 を打撲、胸部痛と呼吸苦が出現し救急搬送。CT検查で縦隔気腫 と左胸䏶内fluid、胸腔ドレナージで胃液様排液を認めた。GS · 食道造影で下部食道の壁損傷と同部位からの造影剂流出を認め緊 急手術の方針となった。上腹部正中切開で手術開始、胸部下部食 道左側後壁に $2 \mathrm{~cm}$ の裂創を認めこれを縫合閉鎖した。術後第12 病日に自宅退院となった。【まとめ】食道損傷は早期診断と早期
治療が生命予後に直結する。病態は多様であるが症例に応じた適 切な対応が肝要である。

3 食道裂孔ヘルニアを合併した胃癌に対して腹腔鏡下幽 門側胃切除及びヘルニア修復術を施行した一例

釧路ろうさい病院 1 、北海道大学 消化器外科学教室 $\mathrm{I}^{2}$

山本葉一1、石川隆壽1、海老沼翔太 1 、村田竜平1、石黒友唯1、小 林清二1、小笠原和宏1、高橋弘昌1、武冨紹信 ${ }^{2}$

症例は70代女性。CEA高值の精查目的に近医の上部消化管内視 鏡検查にて胃幽門前庭部に陥凹性病変を認め生検で adenocarcinomaの診断となった。当院紹介受診し、精查で深達度はMP、 遠隔転移は認めなかったが、高度の食道裂孔ヘルニアを認めた。 食道裂孔ヘルニアを合併した進行胃癌の診断で腹腔鏡下幽門側胃 切除（D 2 ）及び食道裂孔縫縮術を施行した。Rou-en Y 法にて 再建した。病理組織診断はL, Type $2,3.0 \times 2.8 \mathrm{~cm}$, tub $2>$ tub 1 , pT 3 , INFc, ly 1 a, v 1 a, pN $0(0 / 48)$, pPM 0 , pDM $0, \mathrm{M}$ 0 Stage II Aであった。術後経過良好にて術後15日目に退院し た。術後 6 ケ月経過した現在愁訴なく無再発で外来通院中である。 食道裂孔へルニアを合併した胃癌に対して同時手術の報告は少な く、また腹腔鏡を用いた手術となるとさらに少ない。今回安全に 施行しえたため、若干の文献的考察を加え報告する。

4 modified SOFY 法による再建を施行した腹垫鏡下噴 門側胃切除術の一例

市立室蘭総合病院 外科 - 消化器外科 1 、札幌医科大学 消化器 . 総合、乳腺 $\cdot$ 内分泌外科学講座 ${ }^{2}$

木村明菜 1 、斎藤慶太 ${ }^{1}$ 、村松里沙 ${ }^{1}$ 、宇野智子 1 、小川宰司 ${ }^{1}$ 、佐々 木賢一 1 、竹政伊知朗 2

【はじめに】噴門側胃切除術後は吻合部狭窄や逆流などが問題と なることが多く、様々な再建方法が試みられている。【症例】 60 代の男性。意識消失を主訴に救急搬送され、Hb 2.4の高度貧血を 認めた。胃体上部小弯側に $3 \mathrm{~cm}$ 大の 1 型病変を認め、精査にて 胃癌 cT 1 bN 0 M 0 , cStage I と診断し手術を行った。【手術・術 後経過】腹腔鏡下噴門側胃切除術、D 1 + 郭清を施行し、modified SOFY法（以下、mSOFY法）での再建を行った。術後 7 日 目の上部消化管造影検查で、造影剂の残胃への通過は良好で、頭 低位での逆流が無いことを確認した。食事摂取も十分で、合併症 なく良好に経過した。【考察】mSOFY法は、食道と胃をオーバ ーラップさせ、食道を扁平に縫い付けることで強力な逆流防止機 構を有する。加えて、リニアステープラーでの狭窄予防と、手術 手技の簡便化を目的に考案された再建方法である。本術式を採用 し、良好に経過した一例を経験したので、若干の文献的考察を加 えて報告する。

5 食道胃接合部癌に対し腹臥位胸腔鏡下 Mckeown 手術 を施行した 2 例

北海道大学 消化器外科 II

大川裕貴、海老原裕磨、田中公貴、中西喜嗣、浅野賢道、野路武 寬、倉島 庸、村上壮一、中村 透、土川貴裕、岡村圭祐、七戸 俊明、平野 聡

【はじめに】食道胃接合部癌は局在により術式の検討が必要とな る. 今回, 当科にて食道胃接合部癌 2 症例に対し腹臥位胸腔鏡下 Mckeown 手術を施行したので報告する.【術式】胸部操作は腹臥 位で右人工気胸下に施行. 縦郭内のリンパ節郭清は中下縦郭とし, 食道は奇静脈弓の高さで切断した. 胃管作成は腹腔鏡下にて胃管 
を作成. 頸部操作は左側のみ襟状切開し, 胸骨後経路にて䅡部食 道胃管吻合を行った. 【症例 1】71歳男性. EG, Type 2 , tub 2 T 2 N 1 M 0 Stage II の診断にて手術施行. 手術時間342分.出血 $80 \mathrm{ml}$. 術後経過良好にて術後 21 日目に退院となった.【症例 2】72 歳男性. EG, Type 2, tub T 2 N 1 M 0 Stage II の診断にて手術施 行. 手術時間 481 分. 出血 $200 \mathrm{ml}$. 術後胸腔内出血を認めたが経過観 察で改善し術後26日目に退院となった.【結語】腹臥位胸腔鏡下 Mckeown 手術は,吻合不全の際のマネージメントが比較的容易で ある点から, 高位胸垫内吻合が必要な下部食道進展を認める食道 胃接合癌に対する選択術式の 1 つと考えられる。

\section{6 胃軸捻転に伴う脾臓損傷により腹腔内出血を来した 1 \\ 例}

市立札幌病院 外科

上坂貴洋、田中友香、菊地弘展、片山知也、奥田耕司、砂原正男、 大島隆宏、三澤一仁

症例は88歳男性。腹痛を主訴に前医を受診した。血液検查で $\mathrm{Hb}$ $8.7 \mathrm{~g} / \mathrm{dl}$ と貧血を認め、腹部造影 CT で脾臓周囲に造影剂の extravasationを認めた。脾損傷による腹腔内出血が疑われ、当院 搬送となった。精查の結果、胃軸捻転および脾臓周囲の静脈性出 血が疑われたことから、緊急試験開腹の方針とした。開腹時、腹 腔内には多量の血腫が貯留しており、可及的にこれを除去した。 胃体部大弯側が左横隔膜下に落ち込み、また幽門が噴門のすぐ腹 側に位置しており、胃軸捻転と判断した。脾臓を確認すると、被 膜の一部が損傷し、同部位から持続的な出血を認めた。圧迫や熱 凝固での止血が困難であったため、脾臓は摘出した。術後経過は 良好であり、術後 9 日目に退院となった。直近に腹部外傷の既往 はないことから、胃軸捻転により脾臓が牽引され、被膜損傷およ び腹腔内出血に至ったものと考えられた。胃軸捻転による腹腔内 出血は比較的希であり、文献的考察を交えて報告する。

\section{7 成人胃軸捻転症の一例}

札幌厚生病院

小柳 要、高橋周作、瀬戸嶋佑輔、原田拓弥、北 健吾、舩越 徹、 若山顕治、山上英樹、田原宗徳、田中浩一、秦 庸壮、石津寛之 【背景】成人胃軸捻転症はまれな疾患であるが、診断や治療時期 の判断を誤ると致命的になることもあり、その治療方針の決定は 重要である。【症例】72歳女性【現病歴】腹痛を契機に当院内科 受診。CTで胃軸捻転症の診断となり当科紹介受診され、臨時手 術となった。【既往歴】左腎摘出後（詳細不明）、子宮筋腫のため 全摘出術後【画像所見】腹部レントゲンで左横隔膜下に拡張した 胃泡あり。CTで胃角から前庭部が虚脱をして連続性に回転して おり、臓器軸性の胃捻転が疑われた。【手術所見】胃は著明に拡 張しており、胃の背側に脾臓を蝕知したため捻転の解除を試みる も困難であった。胃前壁を小切開して内容物を吸引し、虚脱させ たのちに改めて捻転を解除した。胃前壁を腹壁に固定して閉創し た。【術後経過】術後 3 日目に胃造影行い、通過障害や胃内容排 泄遅延がないことを確認した。術後 4 日目より食事開始し、術後 8 日目に退院した。【結語】成人胃軸捻転症を経験したため、文 献的考察を踏まえて報告する。
8 胃切除後腸重積の 1 例

岩見沢市立総合病院

寺㠃康展、伊藤浩二、上泉 洋、羽田 力、河合朋昭、谷 安弘、 辻 健志、柏倉さゆり、小林正幸

93歳男性。25年以上前に胃癌で幽門側胃切除 B- II 吻合術の既往 あり。今回、朝からの腹痛、嘔吐あり前医受診、イレウスを疑わ れ当院紹介となった。発熱なく、腹部は全体的に膨満。圧通軽度 認めたが反跳痛は認めなかった。血液検查所見では明らかな炎症 反応上昇を認めなかった。腹部造影 CTでは、ブラウン吻合部口 側腸管の拡張とブラウン吻合部の腸重積の所見を認めた。以上よ り腸重積の診断で緊急開腹手術を施行した。手術所見ではブラウ ン吻合肚門側腸管が口側に向かって約 $10 \mathrm{~cm}$ 重積している所見を 認め、これを用手整復した。重積腸管に壊死所見は無く、また肉 眼的に重積を起こす器質的要因も認めなかった。術後経過は良好 で、術後 8 日目に退院した。外来で施行した上部消化管内視鏡検 查では、B- II 吻合部、ブラウン吻合部含め粘膜病変は認めなか った。胃切除後の腸重積は比較的稀であり、若干の文献的考察を 含めこれを報告する。

9 アナストロゾールの治療中に狭心症が悪化した、高齢 者ER陽性乳癌の 1 例

北海道大学病院 乳腺外科

押野智博、高㠃恵美、萩尾加奈子、鈴木はる菜、山下啓子

【背景】エストロゲンは心血管系に保護的に作用する。20132016年のメ夕解析でエストロゲン産生を阻害するアロマターゼ阻 害薬はプラセボに比べ心血管イベントを有意に増大させると報告 された。我々はアナストロゾール（以下ANA）内服中に狭心症 悪化を 3 度認め、ANAを中止した 1 例を経験した。【症例】初診 時86歳、女性。既往歴：高血圧、狭心症。右乳癌、ER陽性, HER 2 陰性、T 2 (21mm) N 0 M 0 Stage II A と診断。耐術能 を懸念し、非手術としANA内服を開始したが、その後40か月間 に 3 度の狭心症悪化を認めた。(1)開始 18 か月後、狭窄した冠動 脈: \# $150 \%$ 、\# 2 25\%、\# 3 75\%、\# 4 PD $75 \%$ 、\# $525 \%$ 、 \# 6 50\%、\# 7 75\%、\#11 50\%、\#13 distal 75\%、治療内容 : 経 皮的冠動脈形成術（\# 3 , \# 4, 7 , \# 9)。(2)27か月後、（\# 1 75\% , \# 5 75\%, \#6 75\%)、\# 5 - 6 に薬剤溶出性ステント留置。(3) 40 か月後、\#190\%、経皮的冠動脈形成術。腫瘍径は $4.4 \mathrm{~mm}$ に縮 小した。 3 度目の悪化後、ANAを中止し以後無治療とした。中 止後 27 か月経過し、腫瘍径は $7.4 \mathrm{~mm}$ と増大あるが、狭心症悪化 は認めない。

\section{0 術後10年目に大腸転移を来した乳癌の 1 例}

国立病院機構函館病院 外科1、国立病院機構函館病院 病理診 断科 2

守谷結美 1 、鈴置真人 1 、溝田知子 1 、大高和人 1 、高橋 亮 1 小室 一輝 ${ }^{1} 、$ 岩代 望 1 、大原正範 1 、木村伯子 ${ }^{2}$

症例は60代女性. 他院で2007年にER陽性浸潤性乳管癌を手術. 経過中, 骨転移に対して内分泌療法を行っていた。 2017年横行結 腸に 5 型腫瘍が確認され, 腹腔鏡下切除を施行. 病理結果は低分 化腺癌, pT $4 \mathrm{a}, \mathrm{pN} 3$ の進行癌であった．大腸原発としては非典 型的で乳癌大腸転移の可能性も検討されたが, 大腸原発の可能性 が高いと診断された。術後補助化学療法を開始後, 当院へ転医し 2018年 9 月より内分泌療法を開始した．2019年 3 月下部消化管内 視鏡検查で大腸 2 か所に I s 型ポリープを認め, ポリペクトミー を施行し印環細胞癌様の所見が得られた。乳癌大腸転移を疑い, 既往の乳癌, 大腸組織を含め当院で再検討を行ったところ, 既往 
の乳癌は浸潤性小葉癌を考える所見, 既往の大腸癌と今回の切除 標本はCDX $2(-)$, ER $(+)$, GATA $3(+)$ より, 最終的に乳 癌大腸転移と診断した。乳癌の大腸転移は稀で, 文献的考察を加 え報告する.

11 乳癌腹膜転移に対し P-TEGが有用であった一例 東札幌病院 ブレストケアセンター1、東札幌病院 外科2、札幌 医科大学 消化器 - 総合、乳腺 - 内分泌外科 ${ }^{3}$

空閑陽子 1,2 、大村東生 ${ }^{1,2}$ 、柏木清輝 ${ }^{2} 、$ 目黒 誠 2 染谷晢史 2 、竹 政伊知朗 ${ }^{3}$

症例は83歳女性。20年前、他院にて左乳癌の診断で手術を施行さ れた。 3 年前より腹部膨満感を自覚し、前医内科受診。癌性腹膜 炎と診断され、前医外科にて審查腹腔鏡を施行したところ多数の 腹膜播種・腹水を認めた。転移性乳癌 $(\mathrm{ER}+, \mathrm{PgR}+, \mathrm{HER} 2$ score 0, Ki-67 30\%）の診断で、nab-PTX、eribulinが施行され たが、繰り返す嘔気・嘔吐を認めコントロール困難となり療養目 的に当院へ転院となった。GSでは壁外圧迫による幽門輪狭窄、 十二指腸水平部では深部空腸からの腸液の逆流所見を認め排出障 害が示唆された。GradeDの逆流性食道炎も認め、減圧目的に胃 管を留置したが、自宅退院を希望されたためP-TEGを造設した。 造設後、嘔吐なく経過され、訪問看護サービス導入の上自宅退院 となった。なお乳癌に対する治療はFULに変更し、現在まで腫 瘍マーカーの上昇なく経過している。本症例は P-TEG 造設によ りQOLが上昇し自宅退院可能となった有用な症例と考える。若 干の文献学的考察も加えて報告する。

\section{2 薬物療法が著効したHER 2 type男性乳癌の 1 例} 旭川医科大学 呼吸器 - 乳腺疾患センター

安田俊輔、岡崎 智、石橋 佳、北田正博

【背景】男性乳癌は乳癌全体の $0.5 \sim 1.0 \%$ と稀であり, 多くはLuminal typeである。一方, HER 2 type男性乳癌は男性乳癌全体 の0.6 1.2\% と非常に稀であり, 予後不良例が多いとされている. 【症例と臨床経過】75歳, 男性. 膀胱癌㧍よび前立腺癌術後で当 院泌尿器外科を通院中．右上肢の疼痛と浮腫を主訴に当院を受診 した，右乳房の腫脹と同部位の多発皮膚結節，右頸部から上肢に かけての発赤，浮腫を認めた，造影 CTでは右乳房内の結節と多 発リンパ節腫脹, 右胸水の貯留および脊椎を中心とした多発骨病 変が指摘され，FDG-PETで同部位の異常集積を指摘された。生 検の結果, 浸潤性乳管癌, HER 2 Type, cT 4 N 3 M 1, cStage IV と診断された. Docetaxelを含むレジメンでの薬物療法が予定 されたが, 胸水貯留と右上肢の浮腫を考慮しEribrin を含むレジ メンでの薬物療法が施行された。浮腫やリンパ節腫大の改善を認 め, 効果判定は cPRであった. 現在も当科外来にて治療継続中 である，考察を加え報告する。

\section{3 低異型度虫垂粘液性腫瘍 2 例の検討}

北海道医療センター 外科

大畑多嘉宣、鈴木环士、三野和宏、植村一仁、川村秀樹

低異型度虫垂粘液性腫瘍 (Low-grade appendiceal mucinous neoplasm, LAMN）はWHO分類との整合性から大腸癌取扱い規 約第 8 版より揭載されるようになった。LAMNは組織学的には 良性であるが、破裂や穿孔により腹膜偽粘液腫を来たした場合に は予後不良となりうることから borderline malignancyに相当す る疾患とされている。今回 LAMNの 2 例を経験したので報告す る。症例 $1: 58$ 歳女性。2 日前より続く右下腹部痛にて他院より
紹介。CTにて虫垂、虫垂周囲の囊胞性病変を認め虫垂周囲膿瘍 の診断で緊急手術の方針となった。術中所見で虫垂、回盲部およ び右付属器が一塊となっていたため腹腔鏡下回盲部切除、右付属 器切除術を施行した。術後病理組織診断にて LAMN と診断、剥 離面への明らかな腫瘍の露出および右付属器への浸潤の所見は認 めなかった。症例 2:85歳女性。虫垂炎の診断で他院より紹介。 炎症は軽度であり一度抗生剂加療で軽快し、interval appendectomyの方針としたが、待機中に症状が再燃したことから臨時手 術の方針となった。腹腔鏡下盲腸合併虫垂切除を行い、術後の組 織病理所見より LAMN と診断した。断端は陰性であった。2 症 例とも術後再発なく経過している。LAMNに対する術式に関し ては現在のところ明確な基準が定まっていないが、腹腔鏡下アプ ローチも有効な選択と考えられた。

\section{4 増大傾向を示した脾過誤腫の一切除例}

製鉄記念室蘭病院 外科

白土翔太郎、パウデルサシーム、石堂敬太、齋藤崇宏、佐藤彰記、 武藤 潤、東海林安人、長谷龍之介、仙丸直人

【はじめに】脾過誤腫は、正常脾構造の異常な混合比からなる先 天的な良性腫瘍である。稀な疾患であり、剖検では $0.13 \%$ 程度と の報告がある。特有の症状はなく、偶然発見されることがほとん どである。しかし、他の悪性疾患との鑑別が困難なことがあり、 切除献体で確定診断されるものが殆どである。今回我々は術前に 確定診断できた、増大傾向を示す脾過誤腫を経験したため報告す る。【症例提示】 60 代男性。貧血精查目的に他院より 3 年前に当 院消化器内科へ紹介された。上部消化管内視鏡検查にて胃粘膜下 腫瘍もしくは脾腫瘍が疑われ、EUS-FNA での病理結果で脾過誤 腫の診断となった。特に症状はなく、年 1 回の超音波検查にてフ オローされていたが、今回のCTにて著明に増大傾向を認めたた め、切除目的に当科紹介となった。当科では腹腔鏡下脾臓摘出術 施行し、摘出標本で病理学的に赤脾髄型の脾過誤腫の診断となっ た。術後経過良好で術後10日目で退院となった。【結語】良性な 疾患でありながら脾過誤腫は本症例の様に急速な増大を示し、破 裂の危険性もある。約 $25 \%$ 症例が非外傷性脾破裂をきたすとさ れている。このように手術適応になることがあるので厳密に経過 観察を要すると考えられた。

\section{5 脾辺縁帯リンパ腫を腹腔鏡下に切除した 1 例}

北海道がんセンター 消化器外科

小山良太、皆川のぞみ、前田好章、篠原敏樹、濱田朋倫 症例は73歳女性。2018年発汗、倦急感などの症状が出現し、他院 を受診し、腹部超音波検查で腹腔内リンパ節腫大を認めた。その 後精查にて腹腔内リンパ節の多発性腫大と脾腫を認め、sIL $2 \mathrm{R}$ が高值であったため悪性リンパ腫疑いで当院血液内科に紹介とな った。骨髄検查で浸潤を認め、腹腔内リンパ節のEUS-FNA では $\mathrm{B}$ 細胞リンパ腫の診断であった。滤胞性リンパ腫と脾辺縁帯リン パ腫 (splenic marginal zone B cell lymphoma; SMZBCL) が鑑 別として考えられたが、後者であった場合脾臓摘出術のみで骨髄 浸潤も改善するとのことで、当科紹介となった。2019年 2 月に腹 腔鏡下脾臓摘出術を施行した。病理学的所見では、B細胞性悪性 リンパ腫 $(\mathrm{SMZBCL})$ の脾臓浸潤で矛盾しない所見であった。 手術後無治療経過観察の方針となっており、現在のところ再発を 認めていない。脾辺縁帯リンパ腫は稀な疾患であり脾臓摘出術が 第一選択とされている。若干の文献的考察を加え報告する。 
16 膿瘍形成虫垂炎に対するInterval appendectomy後に 虫垂アニサキス症と診断した一例

市立函館病院

白川智沙斗、笠島浩行、小笠原健太、田仲大樹、大渕佳祐、須藤 亜希子、梅原 実、植木伸也、佐藤利行、久留島徹大、鈴木伸作、 中西一彰

消化管アニサキス症は魚介類摂取量の多い本邦で多数の報告例が あるが，ほとんどが胃アニサキス症であり虫垂アニサキス症の報 告は少ない. 今回, 虫垂炎の診断で腹腔鏡下虫垂切除術を施行し, 病理組織学的診断にて虫垂アニサキス症と診断した一例を経験し た. 症例は60歳男性. 虫垂周囲膿瘍を伴う急性虫垂炎に対して膿 瘍ドレナージ，抗生剤治療による保存加療歴があり，待機的に Interval appendectomyを行った。術前 CTでは虫垂腫大は認め ず周囲の膿瘍は消失していた，腹腔鏡下虫垂切除術を施行し術後 経過は問題なく術後 3 日目に退院となった. 病理組織検查にて虫 垂壁内にアニサキス虫体を認め, 虫垂アニサキス症の診断に至っ た．虫垂アニサキス症を含む腸アニサキス症では虫垂炎や腸閉塞 などと症状が酷似していることが多く，術前診断は困難であり摘 出して初めて診断に至ることが多い. 穿孔例なども報告されてお り，低侵襲な腹腔鏡手術は有用であると考えられる.

\section{7 腹垫内デスモイド腫瘍の 1 例}

日鋼記念病院 外科

矢部沙織、高橋秀徳、喜納政哉、高田譲二、益子博幸

症例は47歳、男性。4 日前から持続する発熱を主訴に当院を紹介 受診された。造影 CT 検查で脾弯曲部結腸間膜に約 $10 \mathrm{~cm}$ の不均 一な造影効果を伴う腫瘤を認め、横行結腸は圧排され内腔は狭小 化していた。腫瘍は周囲脂肪織濃度の上昇を伴い胃体中部大弯と も境界不明瞭であった。下部消化管内視鏡検查では、横行結腸脾 弯曲部にスコープ通過不可の内䏶狭小化を認めた。粘膜表面は異 常を認めず、生検の結果は正常腸管粘膜の所見であった。上部消 化管内視鏡検查では胃体中部大弯にびらんおよび圧排による壁の 変形を認めた。びらんの部分は生検を施行し正常胃粘膜の所見で あった。PET-CT㭘查では、腫瘤へのFDGの集積（standard uptake value max 6.68) を認めた。腸管もしくは腸間膜由来の 間葉系腫瘍を疑い、腫瘍摘出術および横行結腸・胃部分切除術を 施行した。術後病理組織学的検查で、横行結腸固有筋層から胃槳 膜下層におよぶデスモイド腫瘍と診断された。術後 1 年経過し、 無再発生存中である。デスモイド腫瘍は組織学的には良性腫瘍で あるが、複数臓器への浸潤性増殖をきたし、切除後の局所再発率 は高いとされる。術前診断に至らないことも多く、原発不明の腹 腔内腫瘍では、デスモイド腫瘍の可能性を念頭においた術前評価 および術式の選択が重要である。

\section{8 慜部皮下に生じた滑液包炎の 2 例}

小樽協会病院 外科. 呼吸器外科

平口菜津美、進藤 学、横山和之、石川慶大、臼井葉月、川村 健

滑液包は生理的潤滑装置であり、過剩な摩擦などにより炎症反応 を引き起こす。臂部皮下に生じた滑液包炎を 2 例経験したので報 告する。症例 $1: 51$ 歳男性。左熨部腫瘤を自覚し当科受診。左熨 部皮下に $7.0 \times 7.0 \mathrm{~cm}$ の軟らかい腫瘤を認めた。皮膚に色調変化や 中心凹䆟は伴わなかった。MRIでは T 1 強調画像で低信号、T 2 強調画像で高信号を示し、囊胞壁に造影効果を伴う囊胞性腫瘤を 認めた。腫瘤摘出術を施行し、病理所見は内面が滑膜様細胞で裏 装された囊胞性病変で滑液包炎と診断された。症例 $2: 66$ 歳男性。
臂部違和感・疼痛で当科受診。左臂部皮下に $3.5 \times 3.5 \mathrm{~cm}$ の軟らか い腫瘤を認めた。皮膚に色調変化や中心凹窩は伴わなかった。単 純 CT で軟部組織濃度の皮下腫瘤を認めた。腫瘤摘出術を施行し、 病理所見は滑液包相当の構造を認め滑液包炎と診断された。滑液 包炎は皮下腫瘤の鑑別診断に念頭に置く必要がある。

19 胞腫の一症例

札幌医科大学 消化器 - 総合、乳腺 - 内分泌外科

及能大輔、伊東竜哉、信岡隆幸、金澤あゆみ、沖田憲司、木村康 利、竹政伊知朗

【症例】76歳女性。20年前に褐色細胞腫に対して腹腔鏡下左副腎 切除術を施行。切除断端陰性であった。無症状で経過していたが、 整形外科手術の麻酔導入時に異常高血圧がみられ、血中、尿中力 テコールアミンが高值であった。腹部 CT で腹腔動脈左背側に $18 \mathrm{~mm}$ 大の腫瘤がみられ、褐色細胞腫の再発と診断された。他部 位に明らかな転移はみられず、手術目的に当科紹介となった。

【手術】 5 portで手術を開始。小網を切開して膵上縁に到達し、 術中超音波検查で腹腔動脈左背側に腫瘍を確認した。周囲リンパ 節も含めて腫瘍を摘出した。手術時間198分、出血量 $5 \mathrm{~mL}$ 。

【病理診断】前回手術時と類似した形態の細胞がみられ、chromogranin A、synaptophysin、CD56が陽性で褐色細胞腫の再発 と診断された。

【結語】褐色細胞腫の多くは病理学的な良悪性の鑑別は困難であ り、長期的な経過観察が必要である。

\section{0 単孔式腹腔鏡下手術を施行した小腸 GIST の 1 例} 網走厚生病院 外科

杉井沙織、相山 健、横山良司、中野詩朗

症例は 80 代、男性。ふらつきを主訴に当院を受診し、 $\mathrm{Hb} 7.2 \mathrm{mg}$ ／ $\mathrm{dl}$ と貧血所見を認めた。 2 年ほど前にも同様のエピソードがあり 上下部内視鏡検査を行うも明らかな出血源は指摘できず、小腸腫 瘍からの出血が疑われていた。時折進行する貧血以外には所見が なく、高齢のため経過観察となっていた。輸血等で保存的治療を 試みるも食事再開と同時に貧血が進行するため手術治療の方針と なった。CTでは上部空腸に壁外発育型腫瘤が認められ、小腸 GISTが疑われた。局在の同定も可能と判断し単孔式腹腔鏡下手 術を施行した。トライツ䨣帯より $50 \mathrm{~cm}$ 肛門側に腫瘍を確認でき、 創部から体外に引き出し小腸部分切除を施行した。貧血所見は己 善し術後 7 日目に退院となった。摘出腫瘍は c-Kit陽性でGIST の組織像に該当し、核分裂像 $0 / 50 \mathrm{HPF}$ より低リスクと分類され た。現在再発なく経過している。小腸GISTに対しては、局在の 同定が可能であれば小腸の可動性を活かした単孔式手術は低侵襲 で良い適応と考える。

21 性のクローン病の一例

市立千歳市民病院 外科

深作慶友、許 理威、安念和哉、福島 剛

【緒言】クローン病には、典型的所見が捉えられず手術標本から 診断される例もある。【症例】43歳、男性。既往歴・手術歴なし。 腹痛・嘔吐を主訴に救急搬入され、小腸イレウスの診断で入院と なる。イレウス管による保存的治療で軽快退院したが、入院時の 腹部 CT 検查で回腸の壁肥厚と炎症所見を認め、精查予定となっ た。退院10日後にイレウス再燃し、腹部 CT 検查では同回腸の炎 
症・狭窄所見を認めた。短期間で繰り返すイレウスであり、診断 的治療目的に単孔式腹腔鏡手術を施行した。回腸末端より $50 \mathrm{~cm}$ 程度口側に炎症性に肥厚し癒着した回腸を認め、小腸腫瘍の可能 性も考虑し切除・再建した。摘出標本は広範な縦走潰瘍を認め、 病理所見では活動性のクローン病と診断された。現在、消化器科 で治療中であるが新規狭窄病変の発症なく良好に経過している。 【結語】中年男性に発症し、イレウスを契機に診断されたクロー ン病の一例を経験した。

\section{2 上腸間膜動脈塞栓症に対し血栓除去を行い腸管温存し}

得た 3 例

市立札幌病院

田中友香、大島隆宏、上坂貴洋、菊地弘展、片山知也、奥田耕司、 砂原正男、大川由美、三澤一仁

【はじめに】上腸間膜動脈閉塞症（以下SMAO）は死亡率が $3-$ 4 割程度と重篤な疾患で, 本症例に対する血行再建の適応は施設 毎に異なる。【症例】症例 1 は72歳男性. SMAOに対し血栓除去 施行し腸切除は施行しなかった。1 か月後に虚血後小腸狭窄あり 小腸 $20 \mathrm{~cm}$ 切除施行. 経過良好で自宅退院となった. 症例 2 は79歳 男性. 術中の血流良好な小腸が $70 \mathrm{~cm}$ と短く, 血栓除去と動脈形成 を施行. 血流改善あり残存小腸 $150 \mathrm{~cm}$ を確保した. 在宅点滴が必 要としたが自宅退院となった。症例 3 は91歳女性. 術中の血流良 好な小腸が $110 \mathrm{~cm}$ と短く, 血栓除去を施行. 血流改善あり残存小 腸 $130 \mathrm{~cm}$ を確保し, 重篤な短腸症候群を回避した.【考察】SMAO の診断で広範な壞死に至っていない場合は,腸管温存を目指し血 栓除去を試みる価値があると考え,当院では心臓血管外科と合同 で術中に術式決定を行っている。【結語】今回我々はSMAOに対 し, 最大限の腸管温存を目指し, 血栓除去を行い血流改善を得ら れた 3 例を経験した。

\section{3 腸管温存できた急性上腸間膜動脈閉塞症の 1 例} KKR 札幌医療センター

阪田敏聖、和久井洋佑、植田隆太、藏谷大輔、今 裕史、武田圭 佐、田村 元、小池雅彦

【背景】上腸間膜動脈閉塞症は,死亡率が30 60\%程度と高く予後 不良な疾患である.近年, 開腹血栓摘除や経皮的血管内治療により 腸管温存できた治療報告が散見されるようになってきた.今回， 我々は試験開腹のみで腸管温存できた急性上腸間膜動脈閉塞の症 例を経験したので報告する.【症例】75歳,男性.突然の腹痛を主 訴に当院へ救急搬送された.腹部全体に強い持続痛を認めるが,圧 痛による増強や腹膜刺激症状は認めなかった.既往歴に狭心症, 慢 性心房細動,閉塞性動脈硬化症があり,抗血栓薬を 2 剂内服してい た.腹部造影 CT 検査にて回結腸動脈分岐部より末梢に造影欠損 と腸管の造影効果不良を認め,上腸間膜動脈閉塞症と診断した.同 日,試験開腹術を施行した.腸管の色調は良好であり,血管拍動も 認めた.ICG 蛍光造影でも腸管血流を確認できたため,腸管切除や 血栓摘除は施行しなかった.術後12時間後の造影 CTにて腸管造 影効果は回復傾向であり,全身状態も良好のため経過観察とした .術後経過も良好であり,術後10日で退院となった。【結語】急性 上腸間膜動脈閉塞症であっても末梢側での閉塞の場合は腸管温存 が期待できるが,試験開腹での腸管 viabilityの確認は必要と思わ れる。
24 手稲渓仁会病院 外科

梅本一史、高田 実、西 智史、古川聖太郎、岡田尚也、武内慎 太郎、今村清隆、山吹 匠、加藤健太郎、木ノ下義宏、安保義恭、 中村文隆、樫村暢一

原発性十二指腸癌は稀な腫瘍で、特に上行部での発生は極めて少 なく、その治療方針や至適術式は確立されていない。今回、十二 指腸部分切除を施行した十二指腸上行部腺癌の 1 例を経験したの で報告する。症例は41歳女性。食後の嘔吐と体重減少を主訴に当 院を受診し、十二指腸上行部腺癌と術前診断した。十二指腸上行 部癌が膵頭周囲リンパ節転移を高頻度に来す根拠にそしいことか ら、膵頭十二指腸切除を回避し膵温存十二指腸部分切除術を施行 した。水平脚から上行脚までを分節状に切除し、十二指腸下行脚 と空腸を吻合し再建した。切除した腫瘍は $6 \mathrm{~cm}$ 大で T $3, \mathrm{~N} 0, \mathrm{M}$ 0 , Stage II A ( UICC $7^{\text {th })}$ の診断となった。術後補助化学療法 として大腸癌治療に準じたCapeOX 4 コースを施行し、現在術 後 2 年 4 ヶ月無再発と良好な経過を得ている。

原発性十二指腸癌はその発生部位によって腫瘍学的性質が異な る。本症例の経験から、必ずしも膵頭十二指腸切除が必要とはな らない可能性がある。

25 Meckel憩室癌が疑われ、重複回腸癌と診断された一例 JR札幌病院 外科

中村泰幸、太田盛道、藤野紘貴、田山慶子、鶴間哲弘、平田公一 終末腸管に発生した重複腸間の癌化は極めて珍しく、本邦では 2009年に大城らが報告したのが第一例とされる。回腸の消化管重 複症の場合, 同じ真性馝室として分類される Meckel憩室との鑑 別が問題になる事が多い。今回我々は、Meckel唕室癌が疑われ、 重複回腸癌と診断された一例を経験したので報告する。

症例は82歳女性。 $\mathrm{H} 31$ 年 2 月より心窩部から右下腹部の疼痛を訴 え近医受診。内服薬での改善にそしく、R 1 年 5 月に施行した CECTで小腸腫瘤を認めたため当科紹介となる。CT画像上では バウヒン弁に近い腸間膜内に $45 \mathrm{~mm}$ 大の不正な形状の腫瘤が見ら れ、辺縁に小腸が癒着していたがその腸管は盲端となっており、 Meckel憩室に付着している可能性が考えられた。手術は腹腔鏡下 に腹䏶内観察し、腸間膜を含む病変が体外へと引き出せないことを 確認後、開腹下に摘出した。術後経過は良好で術後 9 日に退院した。

\section{Meckel唕室内翻による腸重積をきたした 1 例}

小樽掖済会病院

中山健太、植木知身、野田 愛、向谷充宏

【現病歴】症例は30歳代男性。下血、貧血を主訴に近医を受診した。 小腸出血疑いで精查目的に当院消化器内科を受診した。【既往歴】 17歳時に穿孔性虫垂炎で汎発性腹膜炎となり手術既往がある。【画 像所見】造影 CTでは限局的な回腸の壁肥厚と腸管内に $10 \mathrm{~cm}$ 程 度の内部低吸収な腫瘍性病変を認めた。カプセル内視鏡検查、経 肛門的ダブルバルーン小腸内視鏡検查で、バウヒン弁より約 $50 \mathrm{~cm}$ 口側の回腸に $30 \times 100 \mathrm{~mm}$ の有茥性の SMTを認めた。頂部 は一部潰瘍を形成しており、出血の原因と考えられた。腫瘍部に 点墨を行った【手術所見】腹腔鏡下小腸部分切除術を施行したが、 腹部は広範に癒着しており開腹移行した。小腸を検索すると、点 墨部位は憩室が重積していた。重積を解除し憩室を含む小腸を切 除した。手術時間174分、出血量少量であった。【術後病理】異所 性膵を伴う Meckel唕室の重積であった。【考察】成人腸重積は腫 瘍性疾患によるものが多く、Meckel憩室に起因するものは $3.4 \%$ と 報告されている。中でも Meckel鄎室内翻によるものは稀である。 
27 小腸に発生した腸管子宮内膜症の 1 例

北海道消化器科病院 外科

蔦保暁生、森田高行、藤田美芳、田本英司、福島正之、芦立嘉智、 上野 峰

子宮内膜症は子宮内膜組織が異所性に増殖する疾患であり、小腸 子宮内膜症は腸管子宮内膜症のうち $7 \%$ と比較的稀であり、回腸 末端付近を好発部位とする。今回、小腸子宮内膜症の 1 手術症例 を経験したので、文献的考察を加えて報告する。症例は42歳女性。 2 年前に腸閉塞の既往を認めていた。腹痛・嘔吐を主訴に近医を 受診し、腸閉塞の診断でイレウス管を留置された。腹部症状改善 を認め、イレウス管抜去されたが腹痛再燃あり、当院受診となっ た。腹部造影 CTで終末回腸の造影効果を伴う壁肥厚および口側 腸管の拡張を認めた。再度イレウス管を留置し、腸管減圧後に腹 腔鏡下にて手術を施行した。子宮・卵巣には異常所見なく、回腸 末端から口側 $15 \mathrm{~cm}$ 程度の部位に責任病変と思われる腸管を認め、 同部位を含め小腸部分切除術を施行した。経過は良好で術後 9 日 目に退院となった。病理組織診断は小腸子宮内膜症であった。

\section{8} 消化管穿孔、膿瘍形成をきたした II 型腸管症型 $\mathrm{T}$ 細胞 性リンパ腫の一例

旭川厚生病院 外科

間 優衣、武田智宏、佐藤 彩、佐野修平、大野陽介、腰塚靖之、 芝木泰一郎、柳田尚之、池上 淳、赤羽弘充

【緒言】腸管症型 $\mathrm{T}$ 細胞性リンパ腫（enteropathy-associated Tcell lymphoma: EATL) は全消化管覀性リンパ腫の $3.4 \%$ と稀で 予後不良な疾患である。今回膿瘍形成、発熱で発症した II 型 EATLの一例を経験したので報告する。【症例】87歳、女性。発 熱と腹痛を主訴に当院紹介となった。造影 CTでは左下腹部で小 腸が瘤状に拡張し、造影効果を伴う $10 \mathrm{~mm}$ の壁肥厚を伴っていた。 腹腔内遊離ガスは認めなかった。腸管穿孔、膿瘍形成を疑い手術 を施行した。手術所見で小腸と交通のある瘤状の膿瘍腔を認めた ため、小腸部分切除と洗浄ドレナージを実施した。病理検查にて EATLと判明した。経過良好で術後11日目に他科転科となった。 【考察】EATLは出血、発熱、腹痛、穿孔などで発症し予後不良 とされるが、 5 年生存率 $20 \%$ と長期生存例も報告されている。し ばしば病変が同時性に多発することが報告されており、悪性リン パ腫を疑う場合には術中に全腸管を可及的に観察すること、また 術後も厳重な経過観察が必要である。

\section{9 腸管症関連 $\mathrm{T}$ 細胞リンパ腫 II 型の 1 例}

北海道医療センター

鈴木玩士、大畑多嘉宣、三野和宏、植村一仁、川村秀樹 症例は84歳男性。主訴は体重減少と腹部膨満。腹部造影 CTにて $10 \mathrm{~cm}$ 大の小腸腫瘍と周囲リンパ節の腫大を認めた。腫瘍マーカ 一は可溶性IL-2 レセプター抗体のみ高值であった。小腸の悪性 リンパ腫疑いで外科的切除の方針となった。開腹所見にて回腸末 端から $80 \mathrm{~cm}$ 口側の回腸にS 状結腸浸潤を伴う腫瘍を認め、小腸 切除、S 状結腸合併切除を行った。術後経過は良好であり、術後 11日目に退院した。病理組織学的検査で腸管症関連 T 細胞リンパ 腫 II 型の診断となった。

腸管症関連 $\mathrm{T}$ 細胞リンパ腫 II 型は消化管原発悪性リンパ腫の中 でも非常に稀であり、100万人に 1 人の頻度で報告されている。 消化管出血や腸閉塞を契機に発見されることも多いが、穿孔のリ スクが高いことも知られている。非常に稀な腸管症関連 T細胞リ ンパ腫の 1 例を経験した。小腸腫瘍は穿孔のリスクもあるため早 急な外科的切除が必要である。
30 胸腔鏡下手術における左房鉗子を使用した安全な自動 縫合器誘導法の工夫

札棍医科大学 呼吸器外科

多田 周、新井 航、高橋有毅、宮島正博、渡辺 敦

【はじめに】胸腔鏡下解剖学的肺切除術における血管、気管支処 理には自動縫合器が使用されることが多い。しかし、肺動脈、気 管支周囲に炎症性リンパ節の固着や「染込み」のある症例では、 自動縫合器のアンビルの誘導に難渋することも少なくない。従来 ペンローズドレーン、ロブネルネラトンカテーテル等を用いた自 動縫合器誘導法が広く知られている。当科ではこれまで血管、気 管支のテーピングに際し、左房鉗子（和田式No. 2) を使用して きたが、今回同鉗子を用い安全に自動縫合器アンビルを誘導しえ た症例についてその方法を供覧する。【症例と方法】患者は77歳 男性と81歳男性。いずれも左原発性肺癌に対し、完全鏡視下左上 葉切除術を予定したが、A 3 およびA $1+2$ 起始部に染込みリン パ節を認めた。染込みリンパ節を可及的に肺動脈末梢へと剥離し、 肺動脈裏面への自動縫合器のアンビル挿入を試みたが難渋した。 そこで肺動脈頭側から肺動脈裏面を通した左房鉗子でアンビル先 端を把持し、鉗子を愛護的に引き抜くともに、尾側から自動縫合 器を慎重に挿入することにより安全に上葉気管支を処理すること ができた。2例とも自動縫合器の誘導に関した合併症はなかった。 【結語】曲り左房鉗子の使用により、従来のペンローズドレーン、 ロブネルネラトンカテーテルといったデバイスを用いずとも、安 全に自動綘合器を誘導することが可能であった。

31 当院における解剖学的肺切除後の術後肺㾇に対する blood patchにおいて、抗血栓薬の内服による影響の検討

市立函館病院 呼吸器外科

千葉慶宜、大川美穂、鶴田航大、馬渡 徹

解剖学的肺切除後の合併症の一つとして肺瘦の遷延が挙げられ る。術後の肺瘦治療としての胸膜癒着療法の内、自己血の胸腔内 投与（blood patch）が有効であるとの報告があり、当院でも術 後早期から用いている。しかし、自己血を用いる際、抗血栓薬の 内服による影響についてはあまり報告されていない。今回、2015 年 1 月 1 日から 2019 年 6 月 21 日までに当院で経験した解剖学的肺 切除後の肺瘦に対してblood patchによる治療を行った26例を対 象に、抗血栓薬内服群 10 例と抗血栓薬非内服群 15 例に関する臨床 経過の比較、および抗血栓薬内服による治療成績への影響につい て検討したので報告する。

\section{2 縦隔原発䯣外性形質細胞腫の 1 切除例 \\ 札幌医科大学 呼吸器外科}

梅田璃子、多田 周、新井 航、高橋有毅、宮島正博、渡辺 敦 【はじめに】髄外形質細胞腫は骨以外に発生する形質細胞腫の 1 種で、中でも縦隔に原発する病変は極めて稀である。今回、前縦 隔原発の髄外性形質細胞腫の 1 例を経験したので報告する。【症 例】51歳男性。健診の胸部レントゲンで縱隔異常陰影を指摘され た。胸部 CTで境界明暸な最大径 $15 \mathrm{~cm} の$ 前縦隔腫瘤影を認め、 縦隔リンパ節腫大や胸膜播種を疑う所見はなかった。胸腺腫を疑 い、診断、治療目的に手術の方針とした。胸骨正中切開でアプロ 一チし、拡大胸腺摘出術を施行した。心膜、腕頭静脈、肺への肉 眼的浸潤を疑う所見はなかった。術中迅速組織診で未分化悪性腫 瘍との診断であったため、上縦隔リンパ節郭清を追加した。術後 経過は良好で術後第 9 病日に退院となった。病理組織所見は、大 小不同の核異型細胞の壞死を伴う充実性の増殖からなる $15 \times$ 10cm大の腫瘍を認め、免疫染色でLCA、CD79a、CD138がびま 
ん性に陽性であり、腫瘍細胞の約半数でCD20が陽性であった。 CK 7、CK20、c-kit、CD 5、CD15、CD30、PLAP、OCT $3 / 4$

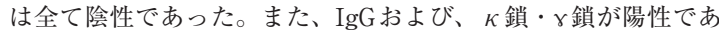
った。以上より縦隔原発形質肺細胞腫と診断した。切除断端は陰 性でリンパ節に腫瘍の転移を認めなかった。【結語】非常に稀な 縦隔原発髄外性形質細胞腫の 1 例を報告した。

\section{3 特発性縦隔気腫の 3 例}

渓和会江別病院 外科

梅本浩平、藤好 直、佐々木彩実、野村 克、大森一吉

特発性縦隔気腫は呼吸器疾患のない健康な人が外傷などの誘因な

く縦隔内にガスが迷入する病態である。比較的稀な疾患とされて いるが、近年報告例が増えている。我々は特発性縦隔気腫の 3 例 を経験したので報告する。自験例 3 例の年齢は16-21歳（平均19 歳)、性別は全例男、BMIは18.0-20.0（平均19.3）であった。2 例は怒責などの誘因を契機に発症した。胸部単純 X線および頝胸 部の CT 検查で縦隔気腫と診断され、上部消化管造影では食道外 への造影剤の漏出は認めなかった。全例入院加療を行い、自然に 治癒し退院となった。入院期間は $7-8$ 日間（平均7.7日間）であ った。特発性縦隔気腫は一過性の肺胞内圧上昇に伴う肺胞損傷が 気管支血管束を経て縦隔に至るものとされている。瘦身の若年男 性に多く発症し、自然に治癒し再発は稀とされている。しかし、 縦隔気腫には食道破裂や気管断裂など致死的な病態が原因となる ものもあるため、慎重に鑑別する必要がある。

\section{4 当院における潰瘍性大腸炎手術症例の検討}

札幌東徳洲会病院 IBDセンター1、札幌東徳洲会病院 外科 2 札幌東徳洲会病院 先端外科センター 3

鈴木悠太 ${ }^{1,2}$ 、伊藤貴博1、古川 滋1、前本篤男 1 、前島 拓 2 、深堀 晋2、吉川大太郎 2 、唐崎秀則 ${ }^{2}$ 、河野 透 ${ }^{3}$

【目的】潰瘍性大腸炎に対する当院での手術成績について検討した. 【対象と方法】2008年〜2019年 6 月まで当院で手術を行った潰瘍 性大腸炎 24 症例.診療録から患者背景および治療情報を収集し後 方視的に検討した。

【結果】男性19,女性 5 例。手術年齢中央値53.5歳 (22-79)。罹病 期間中央值61か月（－382）。䍜患範囲は, 全大腸炎型19,左側大 腸炎型 5 , 直腸炎型 0 。重症度は重症 8 ,中等症 15 , 軽症 1 。手術理 由は難治 13 , 癌 4 , 大量出血 3 , 穿孔 3 , 巨大結腸症 1 。緊急手術 7 . 周術期死亡なし. 各種治療歴は,ステロイド $21,5-\mathrm{ASA} 18$, 生物製 剂14,カルシニューリン阻害剤12,チオプリン製剤10例.

術式はIAA17,結腸亜全摘+回腸ストマ 6 ,大腸全摘 + Miles 1. 合 併症は10例に見られた。 $(10 / 24=41.7 \%)$

【結論】潰瘍性大腸炎の手術では内科と外科の連携が重要と考え られた。

\section{5 術前診断し手術を施行した結腸原発神経内分泌癌の 1 例} 札幌医科大学 消化器 - 総合、乳腺 $\cdot$ 内分泌外科学

三浦 亮、沖田憲司、西舘敏彦、奥谷浩一、碓井彰大、秋月恵美、 浜部敦史、石井雅之、里吉哲太、古来貴宽、竹政伊知朗

【はじめに】大腸神経内分泌癌（NEC）は全大腸癌の $1 \%$ 以下に 認められる稀な腫瘍である。また半数以上は直腸原発であり、結 腸原発は更に稀とされる。今回、術前に診断し手術を行った結腸 原発NECの 1 例を経験したので文献的考察を加え報告する。【症 例】88歳女性。検診で便潜血陽性を指摘され、近医精查で上行結 腸癌と診断、加療目的に当院紹介となった。組織生検の免疫染色
にて synaptophysin 陽性、Ki-67陽性であり、結腸 NEC と術前診 断した。腹腔鏡下回盲部切除術、D 3 を施行、術後病理組織診断 ではpT 3 ,ly 1 a,v 1 b,pN 1 b,pM 0 ,pStage III b、免疫染色にて synaptophysin 陽性、chromograninA 陰性、CD56陰性、Ki-67陽 性率は $70 \%$ の結果であった。現在術後 6 か月、補助化学療法は施 行せず無再発経過観察中。【考察】大腸 NEC は低分化癌や未分化 癌と類似した組織像を呈し、鑑別および術前診断が困難とされる。 また悪性度が高く、根治手術施行後の症例についても早期再発、 死亡に至る報告も多く、術後の慎重なサーベイランスが必要と考 える。

36 術前化学療法にて腺癌成分に対して完全奏功を得た が、NECの遺残を認めた直腸 MANECの一例 札幌医科大学 消化器 - 総合、乳腺 · 内分泌外科 古来貴寛、沖田憲司、西舘敏彦、奥谷浩一、碓井彰大、秋月恵美、 浜部敦史、里吉哲太、石井雅之、三浦 亮、竹政伊知朗

【はじめに】大腸 neuroendocrine carcinoma（以下、NEC）の亜 型として $30 \%$ 以上の腺癌成分を伴うものは mixed adenoneuroendocrine carcinoma（以下、MANEC）と定義されているが報告 は少ない。【症例】67歳男性。肛門痛を主訴に前医受診し、直腸 癌の診断で当科紹介受診。肛門管に高度狭窄を伴い、直腸癌, Rb-P, cT 4 bN 1 M 0 と診断した。術前化学療法を行いcCRの所 見が得られ、腹腔鏡下腹会陰式直腸切断術、D 3 LD 0 を施行した。 摘出標本で腺癌細胞は認めず組織学的効果判定は Grade 3 と診断 された。しかし、クロマチンに富む類円形核を有し、包体にそし い異型細胞が直腸外膜や筋層、肛門挙筋に浸潤し、免疫染色で $\mathrm{CK}-\mathrm{AE} 1 / \mathrm{AE}(+) 、 \mathrm{CK} 7(+) 、 \mathrm{CK} 20(-) 、 \mathrm{CD} 56(+)$ 、chromogranin A (+)、synaptophysin (+)、PSA (-) であり NEC と診断された。現在、NECに対し CDDP+VP16療法を施行して いる。【考察】大腸 MANECの薬物療法として、NEC成分に対し cisplatin+CPT-11や cisplatin+VP16、腺癌成分に対 LFOLFOX の報告があるが、それぞれの成分に対する薬物療法の治療効果を 病理検体にて確認できた報告はなく、今後のMANECの治療戦 略に有用な報告であると考えられる。

37 腺癌と神経内分泌腫瘍を併存した直腸腫瘍の一例 北海道大学病院 消化器外科 I

浜田和也、本間重紀、松井博紀、宮岡陽一、今泉 健、市川伸樹、 吉田 雅、武冨紹信

症例は63歳男性.検診の下部消化管内視鏡検查で $\mathrm{AV} 10 \mathrm{~cm}$ の下部 直腸に $10 \mathrm{~mm}$ 大の 0 - II a + II c 病変を認め生検で adenocarcinomaもしくはneuroendocrine tumor (NET) の疑いとなった. ESDを施行し,病理診断では adenocarcinoma（tub $1>$ tub 2) と NET (Ki-67測定困難, 核分裂像 1 個/HPF) が混在する腫瘍で, NETの成分は $10 \%$ 程度含まれていた.T 1 b,Ly 0 ,V 0 ,BDX,HM $0, \mathrm{VM} 1$ （NET の成分）の為,追加切除目的に当科紹介となった. 術前画像ではリンパ節や遠隔転移を認めなかった.腹腔鏡下直腸 低位前方切除術 D 3 郭清を施行. 手術時間は 3 時間45分, 出血は少 量であった.術後経過は良好で術後14日目に退院した.病理診断で は腫瘍遺残,リンパ節転移は認めなかった.術後 8 ケ月の現在無再 発生存中である.腺癌と神経内分泌癌の成分を $30 \%$ 以上含んだも のとして Mixed adenoneuroendocrine carcinomaが定義される が, 本症例はNET成分が $30 \%$ 未満でこれを満たさない.更に, 同一 病巣内に腺癌と増殖能の低いNETの両成分を含んだ腫瘍は稀で あるとされる.腺癌と NETを併存した直腸腫瘍の一例を経験した。 


\section{8 上行結腸髄様癌の一例}

$\mathrm{JCHO}$ 北海道病院 外科

齋藤智哉、正司裕隆、敦賀陽介、正村裕紀、数井啓蔵

【はじめに】大腸髄様癌はかつては低分化腺癌に分類されており、 本邦では大腸癌取り扱い規約第 8 版で初めて記載された比較的新 しい概念の組織型である。今回、我々は上行結腸髄様癌の一例を 経験したので報告する。

【症例】60歳男性。検診で便潜血陽性を指摘され前医受診し、下 部消化管内視鏡検查にて上行結腸に $2 / 3$ 周性の 2 型腫瘤を認め、 精查加療目的に当院紹介となった。生検の結果、 GroupV,adenocarcinoma,porであり、遠隔転移を認めなかったた め、外科的加療の方針となった。手術は腹腔鏡下右半結腸切除 $(\mathrm{D}$ 3 郭清/FEEA) を施行（手術時間：2 時間55分、出血量 : 40ml)、病理結果は Medullary carcinoma,pT 3 (SS) ,ly 0 ,v $1, \mathrm{pN} 0$,pStage II であった。低分化癌の一種であるため、High risk症例として術後補助化学療法（TS- 1 内服）を施行した。以 後再発なく経過している。【考察】大腸髄様癌は報告例も少なく、 術後補助化学療法や再発時のレジメンなどについて不明な点も多 い。上行結腸髄様癌の一例を経験したため若干の文献的考察を加 え報告する。

39 化学療法により膿瘍化し上行結腸と瘦孔を形成した直 腸癌肝転移の 1 例

札幌センチュリー病院 外科 ·乳腺外科1、札幌センチュリー病 院 内科・消化器内科 2 、札幌医科大学 第二病理学講座 ${ }^{3}$ 小西和哉1、荒谷 純1、永㴊 誠1、坂本 尚1、町田卓郎2、村田 雅樹 3

大腸癌肝転移が消化管と瘻孔を形成する病態は稀である。自験例 を報告する。症例は72歳男性。主訴は粘血便、右側腹部痛。2 月前からの主訴あり当院を受診した。精査の結果、直腸癌 Rab cT 3 N 2 M 1 a（H 3 ） Stage IV a と診断された。予後規定因子は 肝転移と考えられたので化学療法の方針となり FOLFIRI+Bmab を開始した。4コース施行後に熱発、腹痛、食欲不振あり救急搬 送された。肝転移が膿瘍化したと診断し経皮経肝膿瘍ドレナージ を施行した。肝膿瘍は上行結腸と瘦孔を形成しており便汁を混じ た排液が持続した。化学療法休止中に直腸狭窄が進行したので低 位前方切除、左精囊合併切除、回腸人工肛門造設術を施行した。 病理組織学的所見は Rab 2 型 $80 \times 80 \mathrm{~mm}$ tub 1 pT 3 int INFb ly 0 v 2 PN 1 pN 1 (3/3) pPM 0 pDM 0 pRM 0 であった。術 後 CTで肺転移 (PUL 2) が出現した。肝転移、肺転移に対して FOLFOX+Bmabを開始した。肝膿瘍部分は著明に縮小、他の肝 転移、肺転移に対してはSDの効果であった。9コース施行後に 小腸壊死を発症したので緊急に小腸切除術を施行したが敗血症で 死亡した。

\section{0 肝膿瘍を契機に診断し得た早期直腸癌の 1 例}

苫小牧市立病院 外科

南波宏征、財津雅明、花本尊之、廣瀬邦宏、松岡伸一

症例は65歳、女性。1 ケ月前から持続する発熱を主訴に近医を受 診し、肝膿瘍の診断で当院消化器内科へ紹介受診となった。来院 時著明な炎症反応上昇と CT で肝 S $4 / 5$ に $5 \mathrm{~cm}$ 大の肝膿瘍を認 め、同日経皮経肝膿瘍ドレナージを施行した。その後炎症反応は 改善し、第 6 病日チューブ抜去となった。ドレナージ時の細菌培 養は陰性だった。入院中の CSで直腸 $\mathrm{Rb}$ の肛門管近傍に $30 \mathrm{~mm}$ 大 の 0 -I型病変を認め、生検の結果 tub 2 であった。同部位に対し てESDを施行するも、pTx,INFb,ly 0 ,v 3 ,PN 0 ,PM 1 ,DM 1 の診
断で追加切除目的に当科紹介となり、腹脉鏡補助下腹会除式直腸 切断術、D 2 郭清を施行した。術後経過に大きな問題なく、第 15 病日退院となった。病理の結果はESD後の潰瘍のみで、腫瘍残 存は認めなかった。術後 6 年が経過し現在無再発生存中である。 今回、肝膿瘍を契機として早期直腸癌の診断に至った 1 例を経験 したため文献的考察を加えて報告する。

41 腸切除術を施行した 1 例

旭川赤十字病院 外科

窪田武哲、山本和幸、高野博信、西上耕平、市村龍之助、真名瀬 博人、平 康二

症例は70歳代、男性。貧血精查の大腸内視鏡検查にて上行結腸癌 を指摘された。術前精查にて T $2, \mathrm{~N} 0, \mathrm{~N} 0$ stage 1 の診断で手 術の方針となった。血小板無力症を指摘されており、血液内科に コンサルトし、過去に血小板輸血歴がないことから、周術期は血 小板輸血にて対応する方針となった。また不安定狭心症の既往が あり、抗血小板薬を内服しており、手術 1 週間前より入院、ヘパ リン置換を施行した。術前日に血小板 20 単位を輸血し手術を施行 した。予定通り、腹腔鏡下右半結腸切除術施行（手術時間 2 時間 8 分、出血量 $28 \mathrm{ml})$ 。術直後よりドレーンから時間 $30 \mathrm{ml} \sim 80 \mathrm{ml}$ の 血性排液を認め、血小板を 20 単位ずつ輸血し、当日 60 単位輸血し た時点で排液の減少を認めた。 $\mathrm{Hb}$ は約 $13 \mathrm{~g} / \mathrm{dL}$ から約 $10 \mathrm{~g} / \mathrm{dL}$ ま で低下したが、以降は貧血の進行がなく、濃厚赤血球の輸血は要 することなく経過し、退院に至った。今回、血小板無力症を伴う 上行結腸癌に対し腹望鏡下右半結腸切除術を施行した 1 例を経験 したので、その周術期管理について考察し報告する。

\section{2} 第X因子欠乏症が疑われた下行結腸癌の 1 例 札幌北榆病院

木井修平、後藤順一、佐藤正法、服部優宏、高橋宏明 症例は71歳男性、2019年 4 月、便秘、腹満で当院消化器内科受診。 CT 検查で下行結腸癌とそれによる腸閉塞の診断となり入院。経 肚門イレウス管で減圧処置施行。入院 11 日目に開腹左半結腸切除 術を施行。術後第 7 病日に発熱、腹痛は認められなかったものの ドレーン排液が便汁様となり、ドレーン造影で縫合不全を確認。 絶食、抗生剂およびドレーンの持続洗浄を開始した。第XI因子が $39 \%$ と低下していたため、第10病日に第X四因子製剤投与を開始し た。投与開始後 3 日目に瘦孔は閉鎖し、経口摂取を開始。第 22 病 日に軽快退院した。病理は adenocarcinoma,T 3, N 1 b, M 0 , stage III bで、現在術後補助化学療法を施行中である。第XI因子 は凝固因子の一種であり、その欠乏により出血傾向や創傷治癒遅 延が生じることが知られている。今回我々は第XI因子久そ症が疑 われた下行結腸癌の 1 例を経験したので報告する。

43 膿瘍形成を伴う大腸憩室炎に対する保存加療後腹腔鏡 下手術の有用性

市立旭川病院 外科

阿部紘丈、村上慶洋、岡崎 遼、山田 徹、本谷康二、武山 聡 笹村裕二、子野日政昭

膿瘍形成を伴う大腸憩室炎に対する外科治療としては、従来は開 腹によるハルトマン手術が広く一般的に行われていた。しかし、 炎症の程度により重症度が様々であることや、良性疾患であるこ とから手術適応・術式選択について慎重な判断が必要とされている。 当院では限局性腹膜炎症例までは保存加療を先行し、保存加療抵 
抗性の症例や膿瘍形成を反復する症例、他臓器との瘻孔を形成し た症例に対して、手術加療を行っている。2014年から現在までに 保存加療後に手術加療を行った 7 例に対し検討を行った。全例に おいて腹腔鏡手術にて 1 期的切除吻合が可能であり、ストーマ造 設症例は認めなかった。手術時間は179分 (110-255分)、出血量 は150ml (20-340ml) であった。術後平均在院日数は8.57 2.56 日であった。 $\mathrm{CD}$ 分類 3 以上の合併症は 1 例のみで、縫合不全は 認めなかった。当院における膿瘍形成大腸㮩室炎に対する治療成 績を文献的考察を加え報告する。

\section{4 爪楊枝誤飲による横行結腸穿通の一例}

旭川厚生病院

佐野修平、間 優衣、武田智宏、佐藤 彩、大野陽介、腰塚靖之、 芝木泰一郎、柳田尚之、池上 淳、赤羽弘充

【症例】79歳, 女性。【現病歴】持続する腹痛と左上腹部に強い圧 痛を認め消化器内科を受診した。CTにて横行結腸腹側に線状の 構造物と周囲の脂肪織濃度が上昇しており, 当科へ紹介となった。 魚骨などの異物誤飲による消化管穿通疑いで入院，抗生剂による 加療を開始し, 炎症を軽減させてから, 入院 16 日目に異物除去目 的に手術を施行した。【手術所見】上腹部正中切開で開腹し, 網 囊を開放すると, 胃体部大弯側〜横行結腸にかけて膿瘍を形成し ており，一部から $65 \mathrm{~mm}$ 大の爪楊枝が摘出された。膿瘍壁を構成 していた横行結腸は硬く，狭窄しており，爪楊枝が横行結腸壁を 貫いていた可能性も考慮し, 横行結腸部分切除を施行した。切除 した横行結腸の内腔を確認すると, 爪楊枝が粘膜面を貫いて穿通 していた形跡を確認できた。【考察】爪楊枝の誤飲は比較的まれ であり，診断は困難であるが，消化管異物を疑った場合には念頭 において診療すべきと考えられた。

\section{5 当院における直腸脱に対する腹腔鏡下直腸固定術の経験} 釧路ろうさい病院

村田竜平、山本葉一、海老沼翔太、石黒友唯、石川隆壽、小林清 二、小笠原和宏

直腸脱は肚門疾患の中でも比較的頻度は低いが, 近年の高齢化に 伴い症例が増加している.経会陰式手術に対して, 直腸固定術を はじめとする経腹式アプローチは再発率が低く, 近年では腹腔鏡 下手術の有用性が報告されている。当院では,直近 3 年間に直腸 脱に対して腹䏶鏡下直腸固定術を 9 例実施した. 全例 sudeck 法 にて実施し, 平均手術時間96分, 平均出血量 $0 \mathrm{ml}$, 平均在院日数は 7.8日であった. 合併症としては, 内服で対応可能な排便障害が 1 例, 再手術を必要としない軽度再発が 1 例であった. 5 例は経会 陰式手術の再発後であった. 腹腔鏡下直腸固定術は安全かつ再発 率も低く, 有用な術式であると思われた。

\section{6 低異型度虫垂粘液性腫瘍の 1 例}

小樽市立病院 外科

小野 仁、市村健太郎、葛西弘規、渡辺義人、越前谷勇人 症例は47歳、女性。9 日前より心窩部痛を認め、3 日前より右下 腹部に痛みが限局してきた。発熱も出現し、当院消化器内科を受 診した。右下腹部に圧痛を認め、WBC10,300、CRP1.13と軽度の 炎症反応上昇を認めた。CTにて、虫垂の腫大と壁肥厚、周囲脂 肪織濃度の上昇を認め、急性虫垂炎と診断され、当科紹介となっ た。手術適応と判断し、同日単孔式虫垂切除術を施行した。術後 病理標本より、低異型度虫垂粘液性腫瘍と診断された。低異型度 虫垂粘液性腫瘍は、組織学的には良性でも、破裂や粘液の漏出で
腹膜偽粘液腫をきたす可能性があり、境界悪性腫瘍と考えられて いる。治療法に関しては明確なガイドラインは存在していない。 今回われわれは、術前 $\mathrm{CT}$ にて囊胞性病変を認めない、低異型度 虫垂粘液性腫瘍の 1 例を経験したので、若干の文献的考察を含め 報告する。

\section{7 急性虫垂炎を契機に診断された虫垂NETの一例}

恵み野病院 外科

羽田光輝、森田恒彦、林 俊治、中村貴久

症例は20歳代女性で右下腹部痛を主訴に受診。単純 CT T゙虫垂腫 大を認め, 急性虫垂炎と診断し腹腔鏡下虫垂切除術を施行. 病理 組織学検查でクロマチンの増加を伴う類円形の異型核と好酸性の 細胞質を有するおおむね均一な細胞成分で構成される腫瘍性病変 を指摘された。免疫染色は chromogranin A: 陽性, synaptophysin: 陽性，CD56:陽性であった。核分裂像は目立たず Ki-67index: $5 \%$ であり, 虫垂神経内分泌腫瘍（NET G 2) と診断した。術 後に造影 CTで明らかな遠隔転移のない事を確認した上で追加切 除の方針とし, 初回手術から約 2 力月後に, 腹腔鏡下回盲部切除 術（D 3 郭清）を施行した。病理組織学検査では傍腸管リンパ節 と周囲の繊維結合組織内に, 核小体著明な卵円形核と好酸性顆粒 状の胞体を有する腫瘍細胞の増殖を認めた. 虫垂 NET は切除虫 垂の $0.5 \%$ 程度に認め, 若年者にも発生しうる腫瘍である. 今回 我々は急性虫垂炎を契機に診断された虫垂NETに対して追加切 除を行った一例を経験したので文献的考察を加えて報告する.

48 急性穿孔性虫垂炎と診断した盲腸穿孔の 1 例 KKR札幌医療センター 消化器外科

和久井洋佑、植田隆太、阪田敏聖、藏谷大輔、今 裕史、武田圭 佐、田村 元、小池雅彦

【緒言】大腸穿孔は致死率の高い重篤な疾患である。【症例】58歳, 男性. 1 年前より腎硬化症による慢性腎不全に対し血液透析が施 行されていた。主訴は腹痛, 嘔吐, 発熱. 前医受診時に血圧低下 と左前腕シャント閉塞を認め, 当科搬送された。来院時血圧は安 定していたが, 右側腹部に強い自発痛と圧痛, 反跳痛を認めた. 腹部造影 $\mathrm{CT}$ 検查で虫垂の腫脹と虫垂根部の壁の断絶があり, 周 囲に腹水貯留も認めた. 同日穿孔性急性虫垂炎の診断で緊急手術 を施行, 盲腸腹側に黒色壊死様の穿孔部位を認めた。盲腸外側に 虚血様変化を認めたため, 穿孔部位を含む盲腸を部分切除した. 術後経過は良好で, 術後第28日目に退院した。病理所見は穿孔の 原因を示唆する特異的な所見や腫瘍性病変を認めなかった。【考 察】血液透析患者は大腸穿孔において, 発生率と死亡率の両面か ら高リスクである。【結語】血液透析患者における急性虫垂炎の 術前診断は，盲腸穿孔を念頭に置く必要がある.

49 急性胆囊炎に対する早期腹腔鏡下胆囊摘出術における 細径鉗子を用いた 5 ポートの有用性

砂川市立病院 消化器外科・乳腺外科・緩和ケア外科

中本裕紀、横田良一、石川倫啓、山田健司、細田充主、田口宏一 【背景】TG18において急性胆囊炎では、耐術と判断された場合は 早期の胆囊摘出術が推奨されている。しかし時間が経過し癒着が 強い場合は、副損傷回避のため開腹移行が考慮される。

【対象と方法】2018年 1 月〜2019年 6 月までに当院において急性 胆囊炎に対して早期に腹腔鏡下胆囊摘出術を行った 33 例を、従来 の 4 ポート群と助手がソフト凝固吸引管、細径鉗子を使用した 5 ポート群に分け、手術成績について後ろ向きに検討した。 
【結果】 4 ポート群16例、 5 ポート群17例であった。平均手術時 間はそれぞれ119分、108分 $(\mathrm{P}=0.21)$ 、出血量は $29 \mathrm{ml} 、 10 \mathrm{ml}(\mathrm{P}=0.19)$ でともに開腹移行はなく、有意差は認めなかった。術後に 4 ポー 卜群で膵炎 1 例、 5 ポート群で心不全 1 例を認めたが、両群にお いて胆汁漏や胆管損傷、SSIは認めなかった。

【結語】 5 ポート群では術者の鈿子の入れ替えが少なく、視野確 保が良好で、手術時間・出血量隇少につながる可能性がある。

\section{0 急性腹症をきたした二葉胆囊の一例}

小樽市立病院 外科

市村健太郎、小野 仁、葛西弘規、渡辺義人、越前谷勇人

症例は29歳,女性.突然の下腹部痛を主訴に当院救急搬送された。 血液検查にてWBC 16,100,CRP 22.5 と上昇あり,腹膜刺激所見陽 性であった.MRI検査で胆囊と連続する $12 \times 8 \mathrm{~cm}$ 大の境界明暸, 辺縁整, 内部不均一な囊胞状構造を認め, 辺縁の一部に出血を疑う 所見を認めた.胆囊管の描出は不明瞭であった.胆囊腫瘤,壁内出 血と診断し,腫瘤が巨大であることから開腹胆囊摘出術を施行し た.術中所見では胆囊腫瘤は漿膜に出血や壊死を示唆する所見な く,胆囊管の分岐異常等も認めなかった.切除した胆囊と腫瘤は共 通の胆囊管を認め, 病理組織学的にも筋層を有する粘膜が backto-backで融合し, 漿膜下層を共有する像を認め,二葉胆囊と診断 した. 二葉胆囊は極めて稀な胆囊の形態異常の一つであり,その 報告は少ない. 今回われわれは, 急性腹症をきたした二葉胆囊に 対して胆囊摘出術を施行した 1 例を経験したので報告する.

51 術前に副肝管を認めた急性胆囊炎に対して腹腔鏡下胆 囊摘出術を施行した 1 例

砂川市立病院 消化器外科・乳腺外科・緩和ヶア外科

植林毅行、石川倫啓、中本裕紀、山田健司、細田充主、横田良一、 田口宏一

【背景】副肝管は術前にその存在を把握していても術中に損傷を 生じる危険性がある。胆管区域枝までは修復が必要だが、それよ り細いものは必ずしも要さないとされている。

【症例】82歳女性。総胆管結石に対して内視鏡的採石後。嘔吐を 主訴に受診し、CTで急性胆囊炎と診断。腹腔鏡下胆囊摘出術を 施行した。MRCPでは副肝管が胆囊管に合流する久次の分類で $\mathrm{V}$ 型の胆道走行異常を認めた。胆囊寄りで剥離を心がけたが、剥 離の際副肝管を損傷した。しかし径が細く支配領域は区域以下と 判断し、また中枢側から胆汁流出は認めず、クリップし切離した。 術後合併症なく、術後 6 日目に退院した。

【考察】MRCPでの胆管走行評価、CVS確認、Rouviere溝より腹側 での剥離を行っても B 5 から胆囊管に合流する副肝管損傷を回避 できず頸部処理が必要だったと考えられた。B 5 の一部胆管と判 断し再建を行わなかったが今後についてはフォローが必要である。

52 再肝切除症例に対する腹腔鏡下肝切除術の検討 札幌医科大学 消化器 - 総合、乳腺 - 内分泌外科

永山 稔、木村康利、今村将史、山口洋志、村上武志、佐藤公則、 水口徹、竹政伊知朗

再肝切除では前回手術の癒着から腹腔鏡下手術が施行困難な状況 も予想される。当科における再肝切除術症例の成績を後方視的に 検討した。2010年 1 月〜2019年 5 月までに当科で施行した肝切除 症例 : 384例のうち、腹腔鏡下手術（完全鏡視下または腹腔鏡補 助下）は216例（56.3\%）であった。再肝切除50例（13\%）中、 35 例が開腹 $(\mathrm{O}$ 群)、15例が腹腔鏡下（L群；完全鏡視下 6 例、
補助下 9 例）で施行され、疾患は肝細胞癌/転移性肝癌/その他： 32/17/1例であった。術式は、O群/L群 : 26/13例が部分切除で あり、3 回目以上の肝切除（ 5 例）はいずれも $\mathrm{O}$ 群であった。出 血量 (中央值) は $\mathrm{O}$ 群/L群 : $230 \mathrm{ml} / 35 \mathrm{ml}$ であり、L群で有意に 低值であった $(\mathrm{p}<0.001)$ 。術後在院日数（中央值）は $\mathrm{O}$ 群 $/ \mathrm{L}$ 群 で13日/10日であり、L群で有意に短かった $(\mathrm{p}=0.04)$ 。手術時間 や出血量、合併症発症率に差は無かった。腹腔鏡下再肝切除術は 安全に施行可能であり、再肝切除症例に対する選択肢となり得る。

\section{3 肝細胞癌に対する減量肝切除術の検討}

北海道大学病院 消化器外科 I

旭 火華、神山俊哉、折茂達也、島田慎吾、長津明久、蒲池浩文、 武冨紹信

【背景/目的】進行肝細胞癌における減量肝切除の役割は確立さ れていない。進行肝細胞癌の滅量肝切除の検証を行った。【対象 /方法】当科で肝細胞癌に対する減量肝切除を行った 30 症例を後 ろ向きに検討した。背景因子、手術因子、術後治療、術後の集学 的治療による R 0 達成、成績を検討項目とした。術後の集学的治 療 (再肝切除、IVR等) の治療効果判定目的の画像検查で評価可 能病変を認めなくなった場合を R 0 達成と定義した。【結果】術 後治療によりR 0 を達成した症例は 8 例、 $26.7 \%$ であった。30例 全体の中央生存期間（MST）は 28.4 ケ、 5 生存率は $17 \%$ であっ た。 $\mathrm{R} 0$ 達成症例の MST は 56.5 ケ、 5 生存率は $37.5 \%$ であった。 $\mathrm{R} 0$ 未達成症例の MST は 14.8 ケ月、 5 生存率は $8.1 \%$ であった。【結 語】肝細胞癌減量切除後の術後治療による R 0 達成から予後を改 善できたが、今後、分子標的薬を含めた集学的治療の工夫が必要 であると思われる。

\section{4 若年男性に発生した巨大肝腫瘍の一例}

北海道大学 消化器外科 I

石塚千紘、神山俊哉、浜田和也、吉田祐一、旭 火華、長津明久、 島田慎吾、折茂達也、蒲池浩文、武富紹信

症例は既往のない 10 代男性。近医通院中に、腹部膨満がありエコ 一で肝腫瘍を指摘された。精査で肝右葉〜内側区にかけて $26 \mathrm{~cm}$ 大の巨大肝腫瘍を認め、当科へ紹介となった。肝炎ウイルスマー カーは陰性、AFPは正常值でPIVKA-II の異常高值を認めた。 造影CT/MRIで腫瘍は早期濃染、後期洗い出しを認めたが、 EOB-MRIの肝細胞相で取り込み低下は軽度であり、肝細胞癌と しては非典型的であった。他の良性腫瘍も鑑別に挙がったが、悪 性の可能性が否定出来ないことと破裂の危険性から手術適応とな り、肝右 3 区域切除を施行した。術後経過は良好で、術後10日目 に退院となった。若年者の巨大肝腫瘍の報告は稀であるが、特に 背景肝疾患のない肝細胞癌の報告も散見されている。今回術前診 断に苦慮しつつ、最終的に切除に至った症例を経験した。現時点 で病理結果は未着であるが、結果を踏まえ文献的考察を加えて報 告する。

55 Two-stage hepatectomyで長期生存を得た大腸癌多 発肝転移の 1 例

$\mathrm{JCHO}$ 札幌北辰病院 外科

小林展大、中川隆公、下國達志、西川 眞、高橋昌宏 症例は68歳、女性。56歳の時に腸閉塞を伴う S 状結腸癌、多発肝 転移（右葉21個、左葉 4 個）と診断した。一期的切除では残肝体 積が $443 \mathrm{~cm}^{3}$ (切除率 $64 \%$ ）であったため、門脈塞栓併用の twostage hepatectomyで肝転移巣の完全切除を目指す方針とした。 
初回手術はS 状結腸切除術・D 3 郭清、肝外側区部分切除術（4 ケ所）を施行後、回結腸静脈経路で無水エタノールを注入して門 脈右枝塞栓術を施行。残肝体積が $527 \mathrm{~cm}^{3}$ (切除率 $54 \%$ ） と増大 したのを確認し、初回手術23日後に肝右葉切除術を施行。術後合 併症なく、肝右葉切除13日後に退院した。6r月後、S 2 に残肝 再発を認めたため部分切除術を施行。以後再発なく、初回手術か ら12年経過した現在、disease freeで生存中である。大腸癌多発 肝転移は残肝容量などの点から切除不能と判断されることが多い が、自験例のようにtwostage hepatectomyにより肝転移巣の完 全切除を行うことで長期生存を得られる場合がある。

\section{6 大腸癌以外の転移性肝腫瘍に対する肝切除例の治療成} 績. 一大腸癌肝転移切除との比較北海道がんセンター 消化器外科 前田好章、篠原敏樹、皆川のぞみ、小山良太、島田慎吾、濱田朋倫 大腸癌以外の肝転移切除については evidenceが少なく、肝切除 が標準治療であるのは大腸癌のみである。大腸癌以外の転移性肝 腫瘍に対し肝切除を施行した64例について長期成績および予後因 子を検討した。結果：原発部位は胃 22 例、卵巣 10 例、泌尿器系 6 例、乳腺 6 例、子宮 5 例、食道 5 例、胆管 4 例、他 6 例であった。 肝切除術後の 5 年全生存率は $37 \%$ であり、大腸癌肝転移切除例 (51 \%) にくらべ不良であったが、5 年無再発生存率は $23 \%$ あ゙あ大 腸癌症例 $(22 \%)$ と同等であった。現在まで計 12 例（胃 3 例、卵 巣 2 例、子宮 2 例、乳腺 2 例、泌尿器 2 例、その他 1 例）で肝切 除後 5 年以上の実生存を得ている。肝転移切除後の 5 年無再発生 存率に対する予後因子は肝転移個数（1 個 $\mathrm{P}=0.027 ）$ と両葉転

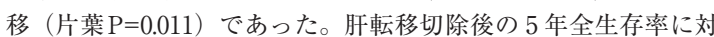
する予後因子は、術前化学療法の効果 $(\mathrm{CR}$ or $\mathrm{PR} \mathrm{P}=0.048)$ で あった。結語：大腸癌以外の肝転移例も、肝切除は有用な治療戦 略になりうる。

\section{7 原発性胆汁性胆管炎の非代償性肝硬変、腎不全に対し} 脳死下肝腎同時移植を実施した一例

北海道大学病院 消化器外科 $I^{1}$ 、北海道大学病院 泌尿器科 2 、 北海道大学病院 臟器移植医療部 3

山本啓一朗1、後藤了一1、樑澤拓夢1、嚴築慶一1、川村典生 1 、渡 辺正明 1 、堀田記世彦 2 、岩見大基 2 、篠原信雄 2 、嶋村 剛 ${ }^{3} 、$ 武富 紹信 ${ }^{1}$

【背景】非代償性肝硬変の合併症として肝腎症候群に起因した腎 不全がある。腎不全が長期化し肝移植のみでの回復が期待できな い場合、脳死下肝腎同時移植による治療戦略が選択肢となる。本 年 5 月より脳死下肝移植はMELD制が適用され肝腎不全の順位 は高くなる可能性がある。【症例】46歳女性。35歳頃原発性胆汁 性胆管炎と診断。43歳時黄疸を認め非代償性肝硬変（T-bil 7.4 $\mathrm{mg} / \mathrm{dl} 、 \mathrm{CTPB} 9$ 点、MELD 7 点) で当院紹介。約 2 年後肝不 全が進行し（T-bil 15.9、CTP C 12点、MELD 22)、緊急度 6 点 で脳死登録された。3 ケ月後T-bil 21.1、MELD 27 と増悪し、肝 腎症候群から透析導入。維持透析導入 8 週後に肝腎同時移植登録 に変更した。待機期間246日、MELD 40の状態で肝腎同時移植を 実施した（手術時間14時間18分、出血量8,890ml）。術後膵炎、急 性尿細管障害を認めたが、肝機能良好に推移し、術後12日目透析 を離脱した。【結語】腎不全を伴う肝不全例は肝腎同時移植の適 応であり、現実的な治療選択肢となっている。
1 例

市立稚内病院 外科

豊島雄二郎、小丹枝裕二、藤好真人

症例は85歳男性。全身浮腫で精查目的に内科入院中。38度台後半 の発熱が 2 日間続き、精查のCT撮像で、左陰囊内にS 状結腸が 嵌頓し、腸管外と思われる air 像あり。周囲の脂肪織の毛羽立ち · 液貯留あり、外科にコンサルト。陰囊内滑脱型鼠径ヘルニア・大 腸穿孔の診断で臨時手術施行。左鼠径部切開法にて、精索内より 穿孔部を含む $\mathrm{S}$ 状結腸を引き出し、創部を延長し、切除。機能的 端々吻合にて吻合。IPT repairにて鼠径管を再建し手術を終了し た。術後経過は良好で術後19日目に退院した。滑脱型鼠径へルニ ア嵌頓の陰囊内での穿孔例は稀であり、若干の文献考察を交えて 報告する。

59 小腸と内側臍ヒダによる閉鎖孔ヘルニア嵌頓に対し水 圧法にて嵌頓を解除しえた一例

北海道社会事業協会 函館病院1、札幌医科大学附属病院 消化 器· 総合、乳腺 $\cdot$ 内分泌外科 ${ }^{2}$

渡久山晃 1 、久木田和晴 1 、岩山祐司 ${ }^{1}$ 、長谷川格 1 、竹政伊知朗 2 症例は86歳の女性。右大腿部の疼痛を主訴に当院へ救急搬送され た。精查にて右閉鎖孔へルニアの診断となり、小腸が嵌頓してい たが用手的還納は不可能であったため、同日緊急手術の方針とし た。腹腔鏡下に観察したところ右閉鎖孔へルニア内に小腸の嵌入 を認めたが、小腸間膜の斢引によっても還納されなかった。ヘル ニア門内にネラトンカテーテルを挿入し、生理食塩水を注入する ことでヘルニア門内の圧を高める水圧法を施行したところ、小腸 は腹腔側へ還納された。さらにヘルニア門内には右内側臍ヒダも 嵌入しており、腹腔鏡下に還納した。ヘルニア門の単純縫合によ る縫縮を行い手術を終了した。今回我々は閉鎖孔へルニアに小腸 と内側臍ヒダが嵌頓している稀な症例を経験し、また水圧法によ り還納しえたため、若干の文献的考察を加えて報告する。

60 ヘルニア門横径 $10 \mathrm{~cm}$ 以上の腹壁瘢痕ヘルニアに対す る治療戦略

手稲渓仁会病院 外科

今村清隆、高田 実、佐々木啓太、市丸千聖、鈴木悠介、萩原詢 哉、原田裕輔、七里圭子、藤井正和、西 智史、梅本一史、古川 聖太郎、岡田尚也、武内慎太郎、山吹 匠、加藤健太郎、木ノ下 義宏、安保義恭、中村文隆、樫村暢一

当科では腹腔鏡下 IPOM 法を2013年、Endoscopic CS 法を2015年、 Endoscopic TAR法を2019年に導入した。癞痕ヘルニアの手術成 績を示し、横径 $10 \mathrm{~cm}$ 以上の症例に対する治療戦略を検討する。 2012年から2019年 5 月までに腹壁痏痕ヘルニア修復術を行った 55 例。67.8 \pm 13.2 歳、BMI $26.1 \pm 3.8$ 、男:女 $=19: 36$ 、ASA ( $1: 2: 3)$ $=(6: 44: 5)$ 、定期:嵌頓による緊急 $=48: 7$ 、EHS 分類での部位 とサイズはL:M:L\&M=12:41:2、W 1:W 2:W 3=12:29:14。初発: 再発 $=50: 5$ 。ヘルニア門横径 $\mathrm{W} 1 \& 2$ と $10 \mathrm{~cm}$ 以上の W 3 に分け て成績を比較した。W $1 \& 2$ 群（n=41）の術式は、IPOM (open/ lap-IPOM/lap- IPOM-plus) $=2 / 24 / 4$ 、RS (open/endoscopic） $=1 / 1$ 、Non-mesh=9 で鏡視下修復術は 29 例（70\%）であ つた。W 3 群 (n=14) は、Lap-IPOM=8、TAR (open/endoscopic） $=1 / 3$ 、 EndoscopicCS $=2$ で鏡視下修復術は 13 例 $(93 \%)$ であった。再発は平均観察期間 30 月でnon-mesh 法で $2 / 9$ 例 (22.2\%)、meshを使用した修復法で $1 / 46$ 例（2.1\%）に認め全て W 1 \& 2 群であった。W 1 \& 2 群と比べW 3 群で手術時間（130 
vs $283 \mathrm{~min}$ ）および術後在院日数（6.0 vs 8.5 days）の延長を認め たが再発や合併症は増加しなかった。ヘルニア門が大きい場合は CSやTAR法などの腹壁再建術が必要になるが、積極的に鏡視下 アプローチで取り組む姿勢である。

\section{1}

当院で経験したIntraductal tubulopapillary neoplasm

の 1 例

NTT東日本札幌病院 外科 1 N NTT東日本札幌病院 消化器内 科 2 NTT東日本札幌病院 臨床検查科病理 - 細胞診検查部門 3 猪子和穂 1 、郭 紗弥 1 、林真理子 1 、道免宽充 ${ }^{1}$ 、市之川一臣 1 、山 田秀久 1 、小野寺学 2 、太宰昌佳 2 、高桑康成 ${ }^{3}$

【背景】Intraductal tubulopapillary neoplasm（以下, ITPN）は 2009年に提唱された比較的新しい疾患概念であり，膵管内腫瘍の 約 $3 \%$ を占める稀な腫瘍である. 今回, 我々は膵頭十二指腸切除 術を施行したITPNの 1 切除例を経験したので報告する.【症例】 69歳, 男性. 近医のPETCTで膵体部にSUV max 6.9の集積を認 め, 膵癌の疑いで精查目的に当院を受診した。CTでは膵体部に $20 \mathrm{~mm}$ 大のそ血性腫瘍を認め, EUSでは主膵管内への進展を疑う 腫瘤および尾側膵管の拡張を認めた。術前に確定診断は得られな かったが, 切除可能膵癌の臨床診断で亜全胃温存膵頭十二指腸切 除術（SSPPD-IIA-1）を施行した，病理所見では，膵管内を充 満するように異型上皮が管状，一部乳頭状に増殖しており，粘液 産生は乏しく，部分的に腺管内に壊死物質を認めた，免疫染色で はMUC 1, MUC 6 が陽性, MUC 2, trypsin, bcl-10が陰性で あり, MUC 5 ACはごく少数の細胞で陽性であるものの大部分で 㓌性であった。以上の所見より，ITPNと診断した。術後は胃内 容排泄遅延を認めたが保存的に改善し, 補助化学療法 (S- 1 単剂) を行った。約 1 年経過した現在, 明らかな再発, 転移は認めてい ない.【考察・結語】術前画像検査で非粘液産生性の膵管内腫瘤 と捉えられる所見を認めた場合はITPNも鑑別に挙げ，浸潤成分 の有無等を考慮し, 手術を含めた治療を検討するべきであると考 えられた。

\section{2 膵体尾部切除術に伴う門脈合併切除の現状と課題}

北海道大学 大学院医学研究科 消化器外科学教室 II

金子 司、中山智英、田中公貴、中西喜嗣、浅野賢道、野路武寛、 中村 透、土川貴裕、岡村圭祐、平野 聡

【背景】門脈浸潤を伴う膵体部癌に対し、教室では積極的に門脈 合併切除 (PVR) を併施した尾側膵切除術 (DP) を施行している。 今回、DPにおけるPVRの手術成績から再建法の妥当性を検討す る。【対象/方法】1998-2017年に教室で施行したDP + PVRの54 例。再建方法は原則、楔状切除後で欠損が大きい場合はパッチ再 建を、環状切除後は切除長 $2 \mathrm{~cm}$ 未満で直接吻合を、それ以上は グラフト間置再建の方針とした。【結果】楔状切除35例、環状切 除18例、非再建 1 例。術中閉塞は 2 例 $(3.7 \%$ )、術後閉塞は 5 例 $(9.3$ \%) 認めた。閉塞を認めた楔状切除 3 例はいずれも大きな欠損に 対する直接縫合症例で、環状切除 4 例も $20 \mathrm{~mm}$ 以上切除後の直接 縫合であった。パッチ再建例、グラフト間置再建例ではトラブル を認めなかった。【結語】大きい楔状切除時や長い環状切除時は、 積極的にパッチやグラフトによる再建を考慮すべきと考える。
63 膵神経内分泌腫瘍と術前診断された腺筋腫（筋上皮性 過誤腫）の一切除例

旭川医科大学 肝胆膵 - 移植外科 1 、旭川医科大学 外科学講座 消化管外科学分野 ${ }^{2}$

齋藤善也 1 、今井浩二 1 、紅露大介 1 、高橋裕之 1 、萩原正弘 1 、横尾 英樹 ${ }^{1}$ 松野直徒 ${ }^{1}$ 角 泰雄 $^{2}$ 、古川博之 ${ }^{1}$

【はじめに】腺筋腫（筋上皮性過誤腫）は、腺や導管の増生とこれら を取り巻く平滑筇細胞や筋線維芽細胞の増生からなる過形成性病変 であり、まれに小腸腫瘤として報告される。今回、術前に膵神経内分 泌腫瘍として診断されたが、術後病理診断で腺筋症（筋上皮性過誤 腫）と診断された一例を経験したので報告する。【症例】40代女性。 3 年前のCTで膵頭部に $10 \mathrm{~mm}$ 大の囊胞性病変を指摘されていた。 3 年後、 CT で $20 \mathrm{~mm}$ 大の囊胞性病変を認め分枝型IPMNと思われ た。しかし、ソマトスタチンアナログシンチグラフィーで膵頭部に集積を 認め、膵神経内分泌腫瘍が疑われ、当科紹介となり膵頭十二指腸切 除術が行われた。術後の病理診断で、拡張したいびつな腺管と、そ の周囲にdesmin・aSMA 陽性の不規則に増殖した紡錘形細胞を認 めたことから、十二指腸から膵頭部にかけての腺筋症と診断された。 ソマトスタチン受容体に対する免疫染色は院性であった。

\section{4 囊胞状の形態を示した膵神経内分泌腫瘍の 1 例} 市立釧路総合病院 外科

宮崎 大、大塚慎也、廣瀬和幸、齋藤博紀、井上 玲、福田直也、 佐藤暢人、飯村泰昭、長谷川直人

膵神経内分泌腫瘍（PNET）は通常充実性腫瘤像を呈するが、囊 胞性変化などの非典型的な画像所見を伴う場合、鑑別が困難となるこ とがある。症例は67歳女性。CTで膵頭部の囊胞を指摘され、精査目 的に当院紹介。膵頭部に $15 \mathrm{~mm}$ 大の囊胞性病変を認め、粘液性囊胞 腫瘍 (MCN) の疑いで带全胃温存膵頭十二指腸切除術を施行。腫 瘍は繊維性の被膜を有する囊胞性病変で囊胞内に出血を伴っていた。 免疫染色ではChromogranin A 陽性、Synaptophysin 陽性、Ki-67 labeling indexは $2 \%$ NET G 1 と診断された。また、主病変の尾 側にも $2 \mathrm{~mm}$ 大の同様の形態の病変を認め、microadenomaと診断さ れた。PNETは囊胞変性を伴う場合もあり、その頻度は9.5-30\%と報 告されている。しかし、本症例のような囊胞主体型の症例は比較的稀 であり、他の囊胞性膵腫瘍との鑑別が困難とされている。本症例でも 術前にはMCNとの鑑別が困難であった。膵囊胞性腫瘍の鑑別疾患と して囊胞主体型のPNETも考慮する必要があると考えられた。

65 泌腫瘍の 1 例

札幌医科大学 消化器 - 総合、乳腺 - 内分泌外科

吉田幸平、今村将史、木村康利、村上武志、永山 稔、山口洋志、 竹政伊知朗

症例は62歳女性.健康診断の腹部USで主膵管拡張を指摘され,前医 を受診した.CTで膵頭部腫瘤を認め,神経内分泌腫瘍疑いとなり当院 紹介となった. CT・MRI 検查では,膵頭部に造影効果を伴う境界明瞭 な $5 \mathrm{~mm}$ 大の類円形の腫瘤と,その尾側膵管の著明な拡張を認めた. EUSでは,膵頭部の低エコー腫瘤として描出され,同部位よりFNAを 施行した.病理組織学的診断では異型細胞を認めたが,挫滅が強く確 定診断には至らなかった.ソマトスタチン受容体シンチグラフィでは,膵頭 部病変に集積はなく,他の部位にも集積はなかった.非機能性膵神経内 分泌腫瘍と診断し,幽門輪温存膵頭十二指腸切除術を施行した.病理 組織診断は主膵管壁へ浸潤する $5 \times 5 \mathrm{~mm}$ 大の非機能性膵神経内 分泌腫瘍 G 1 であった.10mm 以下で主膵管拡張を来した膵神経内分 泌腫瘍は稀であり,若干の文献的考察を加えて報告する。 